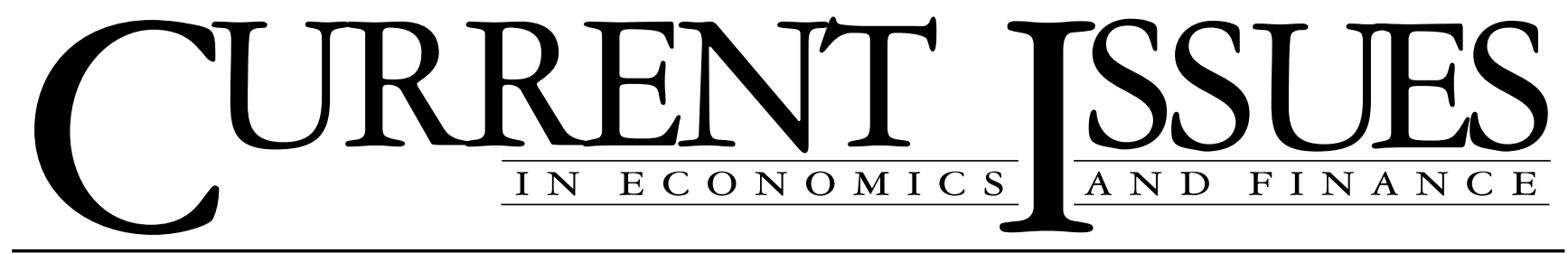

March 1996

Volume 2 Number 3

\title{
Small Business Lending and Bank Consolidation: Is There Cause for Concern?
}

Philip E. Strahan and James Weston

Small banks are a major source of credit for small businesses. As banking consolidation continues, will a resulting decline in the presence of small banks adversely affect the availability of that credit?

In May 1995, Texas became the first state to opt out of the interstate branching provision of the Riegle-Neal Interstate Banking and Branching Act of 1994. In Texas, foes of interstate banking and branching voiced a concern over how consolidation might affect small business lending and community development. If small banks are increasingly acquired by large, superregional banking companies, they argued, consolidation will have a negative effect on the availability of credit to small businesses and communities. Proponents countered by arguing that despite consolidation, the need for independent community banks will remain, leaving an important niche for the small banker to fill.

Who's right? The answer's implications go well beyond the welfare of one state. We can probably anticipate further consolidation in the banking system nationwide as bank holding companies (BHCs) continue to purchase banks and as banks themselves continue to merge. In this edition of Current Issues, we use recent information to analyze the likely consequence of that consolidation for small business lending. The preponderance of our evidence suggests that consolidation will not adversely affect credit availability to small businesses and communities.

\section{Lending Patterns of Small and Large Banks}

Small banks are a primary source of credit for small businesses. Unlike large, publicly traded firms, which have access to capital markets, small businesses rely heavily on banks. ${ }^{1}$ These businesses often concentrate their borrowing at institutions with which they have long-term relationships-relationships that prove mutually beneficial: They enable banks to collect information about the borrower's ability to repay, reducing the cost of providing credit. Borrowers, in turn, enjoy better access to credit and lower borrowing costs. Small banks make more of these "relationship" loans than do large banks, which are more likely to make generic loans based on financial ratios and credit checks. $^{2}$

Large banks may have an advantage in lending to large businesses because they typically offer a wider array of the products and services demanded by their large clients. For instance, large banks can provide more transaction-based services than small banks can. Moreover, large banks are less likely to be constrained by regulatory lending limits. ${ }^{3}$ Even absent explicit lending limits, small banks generally avoid very large loans in order to preserve adequate diversification.

With these considerations in mind, we ask whether consolidation in banking will reduce relationship lending and therefore small business lending. According to one view, relationship loans require tighter control and oversight over loan officers by senior management than do loans based on simple ratio analyses or credit scoring models. As a consequence, the complexity of large 
banks makes relationship loans infeasible (or at least more difficult). Since senior management of small banks can monitor lending decisions closely, they can authorize more non-standard, relationship loans. Therefore, critics of interstate banking and consolidation argue, as small banks disappear no one will be willing to engage in relationship lending. Or, at a minimum, fewer resources will be available to support the kinds of relationship loans upon which small businesses depend.

Others argue, however, that relationship lending will survive bank consolidation because it will continue to be profitable. As large banks acquire smaller banks, they will have a financial incentive to continue to make relationship loans to small businesses. Moreover, if small banks have a cost advantage in providing relationship loans to small businesses, consolidation will not lead to the disappearance of small banks; they will continue to play a vital role at the small end of the lending market.

Table 1

Profile of Small Business Lending by Bank Size

Panel A: Market Shares of C\&I Loans ${ }^{\mathrm{a}}$

\begin{tabular}{lcc} 
Banks by Asset Size & Small C\&I Loans & Large C\&I Loans \\
\hline Less than $\$ 100$ million & 16.3 & 0.3 \\
\$100 million- $\$ 300$ million & 18.3 & 1.5 \\
$\$ 300$ million- $\$ 1$ billion & 13.4 & 3.7 \\
\$1 billion- $\$ 5$ billion & 16.5 & 12.7 \\
Greater than $\$ 5$ billion & 35.4 & 81.9 \\
Totals & 100.0 & 100.0
\end{tabular}

Panel B: Portfolio Shares of Small C\&I Loans ${ }^{\mathrm{b}}$

\begin{tabular}{lcc} 
Banks by Asset Size & $\begin{array}{c}\text { Small C\&I Loans/ } \\
\text { Total C\&I Loans }\end{array}$ & $\begin{array}{c}\text { Small C\&I Loans/ } \\
\text { Total Assets }\end{array}$ \\
\hline Less than \$100 million & 96.7 & 8.9 \\
\$100 million-\$300 million & 85.2 & 8.8 \\
\$300 million-\$1 billion & 63.2 & 6.9 \\
\$1 billion- $\$ 5$ billion & 37.8 & 4.9 \\
Greater than $\$ 5$ billion & 16.9 & 2.9 \\
\hline
\end{tabular}

Source: June 1995 Report of Condition and Income.

Notes: All figures are in percent. Data for small C\&I loans (those under $\$ 1$ million) are based on the original amounts. For large C\&I loans, the figures are computed by subtracting the original amount for small C\&I loans from the book value of all C\&I loans.

a Market shares equal the sum of all small (large) C\&I loans held by banks in that size category divided by the sum of all small (large) C\&I loans made by all banks.

${ }^{\mathrm{b}}$ Portfolio shares equal the sum of all small C\&I loans held by banks in that size category divided by all C\&I loans (assets) held by banks in that size category. These figures are equivalent to weighted averages of the small C\&I loans to total C\&I loans (assets) ratio, weighted by total C\&I loans (assets).

\section{A Profile of Small Business Lending}

In June 1993, the federal banking agencies began collecting data on small business loans. This information appears annually in the June Report of Condition and Income (the Call Report) filed by all commercial banks. The data are collected for three size categories of loans: those whose "original amounts" are $\$ 100,000$ or less, $\$ 100,001$ to $\$ 250,000$, and $\$ 250,001$ to $\$ 1,000,000$. For our analysis, we refer to all commercial and industrial (C\&I) loans under $\$ 1$ million as small business loans. The loan's original amount provides a measure of the total amount of credit extended to the borrower and therefore provides a good proxy for borrower size. ${ }^{4}$

The Call Report data for 1995 enable us to compare the recent small business lending activity of large and small banks. ${ }^{5}$ Large banks make a substantial contribution-35 percent - to the market for loans to small businesses, although this share falls well below their 82 percent share of the large C\&I loan market (Table 1, panel A). ${ }^{6}$ In contrast, small banks focus primarily on small business lending. Banks with assets under $\$ 300$ million hold less than 2 percent of the large C\&I loan market but hold about 35 percent of the small business loan market.

Despite their size difference, small banks can accomplish the same volume of small business lending as large banks because they focus almost completely on this end of the market. The smallest banks held almost 97 percent of their total C\&I loans in small business loans in 1995 (Table 1, panel B). This portfolio share declines as bank size increases; the largest banks devote only about 17 percent of total C\&I lending to small businesses. The share of total assets devoted to small business loans also falls as bank size increases. ${ }^{7}$

These portfolio shares seem to be the main force propelling the foes of interstate banking and bank consolidation. If the portfolio shares remain fixed as the size distribution evolves toward one dominated by large banks, the total availability of small business loans will indeed fall. To see why, imagine shifting $\$ 100$ million in banking assets from the smallest to the largest end of the size distribution (which would occur if a $\$ 10$ billion bank bought a $\$ 100$ million bank). Taking \$100 million in assets away from the smallest banks would lower small business lending by $\$ 8.9$ million (8.9 percent times $\$ 100$ million). Adding that $\$ 100$ million to the largest end of the size distribution would raise small business lending by only $\$ 2.9$ million. The net loss would be $\$ 6$ million. ${ }^{8}$

Note, however, that this experiment does not take into account the dynamic responses of the marketplace to changes in loan availability. Two types of adjust- 
ments are likely. First, if small businesses are not being served because small banks have been acquired, large banks will have a strong profit motive to expand their small business lending. Second, if it turns out that small banks have a cost advantage in providing credit to small businesses (because of their ability to originate and monitor relationship loans), small banking will remain profitable. If this is the case, we should expect that a significant number of small banks will remain viable in the long run and that surviving small banks will increase their emphasis on small business lending. In fact, we see some evidence of this kind of dynamic market adjustment. Between 1993 and 1995, a period of rapid consolidation, the share of total assets invested in small business loans rose by about 5 percent for banks with assets under $\$ 100$ million (from 8.5 percent to 8.9 percent of total assets).

\section{Bank Consolidation and Small Business Lending}

To determine whether consolidation will reduce the availability of small business lending, we consider whether the size and location of bank holding companies affect the propensity of their subsidiary banks to hold small business loans. We also consider whether bank mergers have reduced small business lending.

BHC Ownership and Small Business Lending. The acquisition of banks by large BHCs may reduce small business lending, at least when small banks are acquired by large BHCs. As Table 2 shows, banks with under $\$ 1$ billion in assets hold fewer small business loans when owned by large BHCs. For instance, the typical independent bank with assets under \$100 mil- lion holds 8.7 percent of assets in small business loans, compared with only 6.2 percent for the typical small bank owned by a large BHC. By contrast, banks with more than $\$ 1$ billion in assets hold more small business loans when owned by large BHCs. ${ }^{9}$

Whether a bank is owned by an out-of-state or an instate BHC does not substantially affect the extent of its small business lending. In four of the five bank asset size categories, banks owned by out-of-state BHCs held fewer small business loans. Nevertheless, the difference between the average ratio of small business loans to assets for the two groups of banks is not statistically significant in any of those cases. Overall, it appears that small banks may make fewer small business loans when owned by large banking companies, although the location of the owner relative to the bank seems to have little bearing on small business lending. ${ }^{10}$

Bank Mergers and Small Business Lending. To analyze the effects of consolidation through mergers, we construct a sample of 180 bank mergers that occurred between June 1993 and June 1994. Since only the newly merged bank is observable in 1994 or 1995 , we construct a pro forma bank for each merger by summing the assets and liabilities of the acquiring and target banks in June 1993 (before the merger actually occurred). This pro forma bank provides the benchmark to which we compare the percentage of total assets devoted to small business lending before and after the merger. ${ }^{11}$ A simple before-and-after comparison of small business lending, however, could be misleading because aggregate trends in demand for credit by small borrowers will affect changes in the ratio of small busi-

Table 2

Small Business Loans as a Percentage of Total Assets by BHC Affiliation and Location

\begin{tabular}{|c|c|c|c|c|c|c|}
\hline \multirow[b]{2}{*}{ Banks by Asset Size } & \multirow[b]{2}{*}{$\begin{array}{c}\text { Independent Banks } \\
\text { and Banks Owned } \\
\text { by Small BHCs }\end{array}$} & \multirow[b]{2}{*}{$\begin{array}{c}\text { Banks Owned } \\
\text { by Large BHCs }\end{array}$} & \multirow[b]{2}{*}{$\begin{array}{l}\text { Difference } \\
\text { (T-Statistic) }\end{array}$} & \multicolumn{3}{|c|}{ Banks Owned by Large BHCs } \\
\hline & & & & $\begin{array}{l}\text { Banks Owned by } \\
\text { In-State BHCs }\end{array}$ & $\begin{array}{l}\text { Banks Owned by } \\
\text { Out-of-State BHCs }\end{array}$ & $\begin{array}{l}\text { Difference } \\
\text { (T-Statistic) }\end{array}$ \\
\hline Less than $\$ 100$ million & 8.66 & 6.15 & $\begin{array}{c}2.52 \\
(9.79)^{\mathrm{a}}\end{array}$ & 6.38 & 5.83 & $\begin{array}{c}0.55 \\
(1.11)\end{array}$ \\
\hline$\$ 100$ million$-\$ 300$ million & 9.27 & 7.38 & $\begin{array}{c}1.89 \\
(6.97)^{\mathrm{a}}\end{array}$ & 7.20 & 7.62 & $\begin{array}{c}-0.42 \\
(-0.91)\end{array}$ \\
\hline$\$ 300$ million- $\$ 1$ billion & 7.94 & 6.25 & $\begin{array}{c}1.69 \\
(4.44)^{\mathrm{a}}\end{array}$ & 6.50 & 5.96 & $\begin{array}{c}0.53 \\
(1.02)\end{array}$ \\
\hline$\$ 1$ billion- $\$ 5$ billion & 3.64 & 5.61 & $\begin{array}{l}-1.96 \\
(-2.88)^{\mathrm{a}}\end{array}$ & 5.97 & 5.15 & $\begin{array}{c}0.82 \\
(1.64)\end{array}$ \\
\hline Greater than $\$ 5$ billion & 2.89 & 3.51 & $\begin{array}{l}-0.62 \\
(-0.68)\end{array}$ & 3.78 & 3.12 & $\begin{array}{c}0.67 \\
(1.62)\end{array}$ \\
\hline
\end{tabular}

Source: June 1995 Report of Condition and Income.

Notes: This table presents the simple (unweighted) average share of total assets invested in small business loans for banks in different size categories. All figures are in percent. Data for small business loans (those under \$1 million) are based on the original amounts for C\&I loans. T-statistics in columns 3 and 6 test the null hypothesis that the means in each of the preceding two columns are equal. Large BHCs are defined as bank holding companies with assets greater than $\$ 1$ billion.

${ }^{\text {a }}$ Statistically significant at the 1 percent level. 
ness loans to assets for all banks, apart from the effects of mergers. To isolate these effects, we compare changes in this ratio for the merger sample with a sample of nonmerged banks (the control group). For each merger, we randomly select one nonmerging bank with the same total assets as the pro forma bank in 1993.

Overall Changes after Mergers. The top panel of Table 3 compares the average change in the ratio of small business loans to assets at banks involved in a merger between June 1993 and June 1994 with the change for the control group. The changes for banks involved in mergers represent the average difference between the pro forma bank's ratio of small business loans to assets in June 1993 and the newly merged bank's actual ratio of small business loans to assets in June $1995 .^{12}$ The ratio of small business loans to assets for the pro forma bank in 1993 is a measure of the expected amount of small business lending for the newly merged bank provided that no change occurs in the target bank's propensity to engage in small business lending. If the new management of the target bank reduces its small business lending following the merger, the ratio of small business loans to assets will decline from 1993 to 1995; if management increases small business lending, we should see an increase in that ratio.
As shown, the average ratio of small business loans to assets rose from 8.3 percent in June 1993 for the pro forma banks to 8.5 percent in June 1995 for the newly merged banks. By contrast, the average ratio fell from 7.4 percent to 6.9 percent for banks not involved in mergers. ${ }^{13}$

The same test was performed using three different size classifications for the pro forma bank. Here we found a significant increase in small business lending for small mergers, and no significant difference between the newly merged banks and the control group for medium-size and large mergers. ${ }^{14}$

Changes by Merger Type. Although our evidence suggests that bank mergers do not reduce small business lending on average, certain types of mergers may work to reduce banks' propensity to serve the credit needs of small businesses. For instance, when two medium-size banks combine to form one large bank, the new bank may be so large and complex that relationship loans become more costly. The new, large bank may therefore provide less credit to small borrowers than the two medium-size banks did.

The bottom panel of Table 3 reports changes in the ratio of small business loans to assets (relative to the control group) for our sample of mergers broken down

Table 3

Bank Mergers and Small Business Lending

Panel A: Comparison of Small-Loans-to-Assets Ratio for Newly Merged Banks and Control Group by Size of Pro Forma Bank

\begin{tabular}{|c|c|c|c|c|c|c|c|c|}
\hline \multirow{2}{*}{$\begin{array}{l}\text { Pro Forma } \\
\text { Bank Asset } \\
\text { Size }\end{array}$} & \multirow[b]{2}{*}{$\begin{array}{c}\text { Number of } \\
\text { Banks }\end{array}$} & \multicolumn{2}{|c|}{1993 Small-Loans-to-Assets } & \multicolumn{2}{|c|}{1995 Small-Loans-to-Assets } & \multicolumn{2}{|c|}{$\begin{array}{c}\text { 1993-95 Change in } \\
\text { Small-Loans-to-Assets }\end{array}$} & \multirow[b]{2}{*}{ T-Statistic } \\
\hline & & $\begin{array}{c}\text { Pro Forma } \\
\text { Banks }\end{array}$ & $\begin{array}{c}\text { Control } \\
\text { Banks } \\
\end{array}$ & $\begin{array}{c}\text { Merged } \\
\text { Banks } \\
\end{array}$ & $\begin{array}{c}\text { Control } \\
\text { Banks } \\
\end{array}$ & $\begin{array}{c}\text { Merged } \\
\text { Banks }\end{array}$ & $\begin{array}{c}\text { Control } \\
\text { Banks }\end{array}$ & \\
\hline Less than $\$ 300$ million & 102 & 9.12 & 8.15 & 10.12 & 8.20 & 1.00 & 0.05 & $1.90^{\mathrm{a}}$ \\
\hline$\$ 300$ million- $\$ 1$ billion & 39 & 9.10 & 8.03 & 7.64 & 6.66 & -1.46 & -1.38 & -0.10 \\
\hline Greater than $\$ 1$ billion & 39 & 5.25 & 4.70 & 5.13 & 3.91 & -0.11 & -0.78 & 1.23 \\
\hline All banks & 180 & 8.28 & 7.38 & 8.50 & 6.94 & 0.22 & -0.44 & $1.82^{\mathrm{a}}$ \\
\hline
\end{tabular}

Panel B: Changes in Small-Loans-to-Assets Ratio for Newly Merged Banks Relative to Control Group by Size of Target and Acquiring Banks

\begin{tabular}{lccc} 
Target Bank & Acquiring Bank Is Small & Acquiring Bank Is Medium-Size & Acquiring Bank Is Large \\
\hline Small & 2.17 & 0.06 & -0.13 \\
& $(2.17)^{\mathrm{a}}$ & $(0.09)$ & $(-0.33)$ \\
Medium-size & {$[53]$} & {$[52]$} & {$[14]$} \\
& NA & -0.50 & 1.09 \\
& & $(-0.29)$ & $(0.85)$ \\
& & {$[15]$} & {$[7]$}
\end{tabular}

Source: June 1993-95 Reports of Condition and Income.

Notes: All figures are in percent. Differences are percentage point differences (not percentage changes). In panel B, medium-size banks have total assets between $\$ 100$ million and $\$ 1$ billion, and large banks have assets above $\$ 1$ billion. The average percentage point change in the ratio of small business loans to assets relative to the control group is presented first; the T-statistic testing that the average change equals zero appears in parentheses and the number of observations appears in brackets.

a Statistically significant at the 10 percent level. 
by the size of the target and acquiring banks. ${ }^{15}$ For instance, the first column presents changes in the ratio of small business loans to assets from 1993 (pro forma) to 1995 when the acquiring bank is small. When two small banks merge, we find significant increases in small business lending; otherwise, we find no significant change. ${ }^{16}$

Overall, our research provides no support for the idea that consolidation from bank mergers reduces the portfolio share of a bank's small business loans. If anything, mergers seem to increase banks' propensity to hold these loans. Even when a marked change in the size of the target bank occurs post-merger (for example, when a large bank buys a small one or when two medium-size banks merge), we see no significant decline in the share of resources devoted to small business lending.

\section{Conclusions}

The availability of small business loans has recently received considerable attention in political and academic spheres. The new Call Report data show that small businesses receive credit from banks of all sizes. Both large and small banks are responsible for small business lending, although small banks' C\&I lending is almost completely devoted to small businesses.

Looking ahead, we can probably anticipate further consolidation in the banking industry. Can we conclude that a decline in the presence of independently owned, small banks would have an adverse impact on the credit available to small businesses? The preponderance of our evidence suggests no. Although small banks hold more small business loans as a percentage of total assets than do large banks, the largest banks currently hold more than one-third of all small business loans. Evidently, some large banks find small business lending profitable. We also find that the share of small banks' assets invested in small business loans has risen over the past two years, at least partially offsetting the decline in the number of small banks.

We do find, however, that small banks owned by large banking companies hold fewer small business loans than do independent banks. This may mean that the costs of providing credit to small borrowers are lowest in small banking companies. If so, we would expect at least some small banking companies to survive the wave of consolidation and continue to serve the credit needs of small businesses. Finally, banks involved in mergers, on average, hold more small business loans two years after the merger. Since small business loan data only became available in June 1993, this merger analysis is necessarily limited. As more data become available, the long-run effects of bank mergers on small business loans will likely become clearer.

\section{Notes}

1. According to the 1993 National Survey of Small Business Finances, commercial banks are the most important single source of credit to small firms (Cole and Wolken 1995).

2. Following Berger and Udell (1996), we use the term relationship loan to refer to loans that require borrowers to have established a relationship with the lender before receiving credit. By contrast, standard loans do not require such a relationship. Non-relationship borrowers can be approved if they pass a formal set of criteria based, for instance, on financial ratios, appraisals, and credit scores. See Peterson and Rajan (1994) for evidence on the importance of relationship lending. See Berger and Udell (1996) for evidence that small banks engage in more relationship lending than do large banks.

3. Nationally chartered banks are restricted from making loans greater than 15 percent of capital to a single borrower. Statechartered banks face similar lending limits, although these vary somewhat based on state regulations (Spong 1994).

4. We define small business loans by the loan's original amount, rather than by actual borrower size, since this is how the data are collected. The original amount is defined under the following guidelines: For loans drawn under commitment, the original amount is the size of the line of credit or loan commitment when the line of credit or loan commitment was most recently approved, extended, or renewed before the report date. If the amount outstanding as of the report date exceeds this size, however, the original amount is the amount currently outstanding on the report date. For loan participations and syndications, the original amount is the entire amount of credit originated by the lead lender. For all other loans, the original amount is the total amount of the loan at origination or the amount outstanding as of the report date, whichever is larger.

5. The figures reported for June 1995 in Table 1 are representative of those that prevailed in June 1993 and June 1994.

6. The original amounts for large C\&I loans (that is, loans greater than $\$ 1$ million) are not collected in the June Report of Condition and Income. The figures in Tables 1-3 using large C\&I loans are computed by subtracting the original amount of small C\&I loans from the book value of all C\&I loans. Moreover, we do not have original amounts for banks that report that "all or substantially all" of their loans are below $\$ 100,000$. For these banks, we use the book value of their C\&I loans and assume that 100 percent of these loans are small.

7. Levonian and Soller (1996) also find that small banks concentrate on small business lending but large banks hold a significant share of the small business loan market.

8. Berger, Kashyap, and Scalise (1995) simulate the impact of future consolidation on small business lending holding bank portfolio shares constant. They find a large decline in small business lending, but this simulation experiment does not account for the dynamic market adjustments described in the text.

9. Keeton (1995) finds that multi-office banking companies hold fewer small business loans than single-office banking companies.

10. Whalen (1995) also finds no adverse effects of out-of-state ownership on small business lending by banks in Illinois, Kentucky, and Montana. 
11. We construct a sample of 180 mergers completed between June 1993 and June 1994 from the Federal Reserve System's National Information Center transformation table (a summary of structural changes in the banking industry). We exclude mergers of banks held by the same BHC.

12. We consider the two-year change to allow enough time for significant changes to have been made in the new, merged bank's focus on small business lending. We can look only at two-year changes because we only have small business loan data available in 1993 , 1994, and 1995. Note that the amount of time that has passed from the time of the merger to June 1995 can range from a maximum of two years (if the merger occurred on June 30,1993) to a minimum of one year (if the merger occurred on June 30, 1994).

13. Peek and Rosengren (1996), however, find that small lending falls following mergers, based on a small sample of mergers that occurred in New England during 1993-94. They do not compare the change in small business lending with a control group, nor do they present statistical tests of their findings.

14. We also compared the average change in the ratio of small business loans to assets for the merger sample with a second control group of banks that began the period with similar assets and grew at roughly the same rate over the next two years. We compared the behavior of the merged banks with this second control group because the typical bank involved in a merger may also be a rapidly growing bank. If rapidly growing banks differ systematically from other banks, the comparison of the merged banks with the control group in Table 3 may be misleading. After controlling for asset growth following the merger, however, we found even stronger evidence that mergers increase small business lending.

15. Note that Table 3, panel B, includes only mergers in which the acquiring bank merged with a single target bank during the 1993-94 period.

16. The results in Table 3 were also computed using $\$ 300$ million in assets as the cutoff for the definition of a small bank. These results are almost identical to those presented in Table 3.

\section{References}

Berger, Allen N., and Gregory Udell. 1996. "Universal Banking and the Future of Small Business Lending." In Anthony Saunders and Ingo Walter, eds., Universal Banking: Financial System Design Reconsidered. Burr Ridge, Illinois: Irwin Publishing (forthcoming).

Berger, Allen N., Anil K. Kashyap, and Joseph M. Scalise. 1995. "The Transformation of the U.S. Banking Industry: What a Long Strange Trip It's Been.” Brookings Papers on Economic Activity 2.

Cole, Rebel, and John D. Wolken. 1995. "Financial Services Used by Small Businesses: Evidence from the 1993 National Survey of Small Business Finances.” Federal Reserve Bulletin 81: 629-67.

Keeton, William R. 1995. "Multi-Office Bank Lending to Small Businesses: Some New Evidence." Federal Reserve Bank of Kansas City Economic Review 80(2): 45-57.

Levonian, Mark, and Jennifer Soller. 1996. "Small Banks, Small Loans, Small Business.” FRBSF Weekly Letter no. 96-02.

Peek, Joe, and Eric S. Rosengren. 1996. "Small Business Credit Availability: How Important Is the Size of the Lender?" In Anthony Saunders and Ingo Walter, eds., Universal Banking: Financial System Design Reconsidered. Burr Ridge, Illinois: Irwin Publishing (forthcoming).

Petersen, Mitchell A., and Raghuram G. Rajan. 1994. "The Benefits of Lending Relationships: Evidence from the Small Business Data." Journal of Finance 49: 3-37.

Spong, Kenneth. 1994. Banking Regulation: Its Purposes, Implementation and Effects. Federal Reserve Bank of Kansas City.

Whalen, Gary. 1995. "Out-of-State Holding Company Affiliation and Small Business Lending." Comptroller of the Currency Economic \& Policy Analysis Working Paper no. 95-4.

\section{About the authors}

Philip E. Strahan is an Economist in the Banking Studies Function of the Research and Market Analysis Group. James Weston, formerly an Assistant Economist in the Banking Studies Function, is currently a Ph.D. candidate at the University of Virginia.

The views expressed in this article are those of the authors and do not necessarily reflect the position of the Federal Reserve Bank of New York or the Federal Reserve System.

Current Issues in Economics and Finance is published by the Research and Market Analysis Group of the Federal Reserve Bank of New York. Dorothy Meadow Sobol is the editor.

Editorial Staff: Valerie LaPorte, Mike De Mott, Elizabeth Miranda

Production: Graphics and Publications Staff

Subscriptions to Current Issues are free. Write to the Public Information Department, Federal Reserve Bank of New York, 33 Liberty Street, New York, N.Y. 10045-0001, or call 212-720-6134. Back issues are also available. 